Article

\title{
Pd/DNA as Highly Active and Recyclable Catalyst of Suzuki-Miyaura Coupling
}

\author{
M. Mart ${ }^{1}$, W. Tylus ${ }^{2}$ (D) and A. M. Trzeciak ${ }^{1, * \mathbb{D}}$ \\ 1 Faculty of Chemistry, University of Wrocław, 14 F. Joliot-Curie, 50-383 Wrocław, Poland; \\ mehmet.mart@chem.uni.wroc.pl \\ 2 Faculty of Chemistry, Wroclaw University of Science and Technology, Wybrzeże Wyspiańskiego 27, \\ 50-370 Wroclaw, Poland; wlodzimierz.tylus@pwr.edu.pl \\ * Correspondence: anna.trzeciak@chem.uni.wroc.pl
}

Received: 27 October 2018; Accepted: 13 November 2018; Published: 16 November 2018

\begin{abstract}
Pd} / \mathrm{DNA}$ catalysts were prepared in a mixed $\mathrm{H}_{2} \mathrm{O} / \mathrm{EtOH}$ solvent using palladium precursors, $\mathrm{Pd}(\mathrm{OAc})_{2}$ and $\mathrm{PdCl}_{2}$, in different dosages and salmon fish sperm DNA. As prepared, the $\mathrm{Pd} / \mathrm{DNA}$ contained $\mathrm{Pd}(\mathrm{II})$ and $\mathrm{Pd}(0)$ nanoparticles of various sizes and morphologies, depending on the preparation method. Pd/DNA efficiently catalyzed the Suzuki-Miyaura cross-coupling of various aryl bromides with phenylboronic acids. The catalyst was recovered by simple phase separation and then reused in seven consecutive cycles with a high activity.
\end{abstract}

Keywords: palladium; nanoparticles; DNA; Suzuki-Miyaura; carbonylative coupling

\section{Introduction}

Many aryl compounds, such as acids, amides, ketones, or biaryls are products of palladium-catalyzed coupling reactions which offer efficient and simple procedures for their production [1-7]. Biaryls are used in the production of various pharmaceuticals, polymers, liquid crystals, and ligands. One of the most effective routes to biaryls is the Suzuki-Miyaura cross-coupling of arylboronic acids and aryl halides [8,9]. Ketones are common structural motifs of many natural products, e.g., pharmaceuticals and agrochemicals [10].

The importance of palladium based heterogeneous catalytic systems is growing because of their easy separation from the reaction mixture and their recycling potential. Until now, carbon, magnetic materials, silica, hydroxyapatite, zeolites, nanoparticles, metal organic frameworks (MOFs), organic polymer, clay minerals and bio-supports have been used for this purpose [11]. Among heterogeneous catalytic systems palladium nanoparticles (Pd NPs) have a special place. Pd NPs are used as catalysts in many kinds of reactions, for instance hydrogenation and cross-coupling [12-27].

Recently the peculiar structure of DNA as well as its non-toxicity have attracted the interest of researchers of catalysis and it has been used as a support for immobilization of Pd NPs [28-30]. But until now only one article has been published on testing DNA supported Pd NPs in Suzuki-Miyaura reaction. In this study low efficiency has been achieved with bromobenzene derivatives [31].

Our studies aimed at the synthesis of DNA-supported Pd NPs using different precursors and reaction conditions. We expected to receive active and recyclable catalysts for the Suzuki-Miyaura coupling and to find correlation between the catalyst structure and its activity. 


\section{Results and Discussion}

\subsection{Structure of $P d / D N A$}

Four Pd/DNA samples were prepared under different conditions. As a source of palladium, $\mathrm{Pd}(\mathrm{OAc})_{2}(\mathrm{C} 1-\mathrm{C} 3)$ or $\mathrm{PdCl}_{2}(\mathrm{C} 4)$ were used. The Pd/DNA samples, C1-C4, were characterized structurally using Fourier-transform infrared spectroscopy (FT-IR), X-ray powder diffraction (XRD), X-ray photoelectron spectroscopy (XPS), and Transmission electron microscopy (TEM).

Comparison of the Fourier-transform infrared spectroscopy (FT-IR) spectra of pure DNA with C2 $\mathrm{Pd} / \mathrm{DNA}$ indicated some differences. Thus, symmetric and antisymmetric stretching peaks of $\mathrm{PO}_{4}{ }^{3-}$ observed in pure DNA at 1064 and $1237 \mathrm{~cm}^{-1}$ were weakened for Pd/DNA and shifted to 1055 and $1211 \mathrm{~cm}^{-1}$. In addition, changes were observed in the $1605-1693 \mathrm{~cm}^{-1}$ region, assigned to $v(C=C)$, $v(\mathrm{C}=\mathrm{N})$, and $v(\mathrm{C}=\mathrm{O})$, as well as the weakening of the $v(\mathrm{C}=\mathrm{N})$ band at $1484 \mathrm{~cm}^{-1}$. These FT-IR data indicated that Pd NPs interacted with the $\mathrm{PO}_{2}{ }^{-}$group of DNA and the nitrogen atom that belongs to the base pairs of DNA (see Figure S1).

It was expected that Pd/DNA contained Pd(II) bonded to functional groups of DNA and the XPS method was used in order to confirm oxidation state of palladium. However, the XPS analysis of Pd/DNA $(\mathrm{C} 1, \mathrm{C} 2)$ showed Pd 3d spectra (Figure 1) characterized by the typical two spin-orbit components $\mathrm{Pd}\left(3 \mathrm{~d}_{5 / 2}\right)$ and $\mathrm{Pd}\left(3 \mathrm{~d}_{3 / 2}\right)$ separated by approximately $5.4 \mathrm{eV}$. Figure $1 \mathrm{~b}$,c shows a Pd $3 \mathrm{~d}$ line deconvoluted into two doublets attributed to two different chemical species, $\mathrm{Pd}(0)$ and $\mathrm{Pd}(\mathrm{II})$. The first peak centered at $335.5 \pm 0.1 \mathrm{eV}\left(3 \mathrm{~d}_{5 / 2}\right)$ corresponded to $\mathrm{Pd}(0)$ [12]. The second peak centered at $338.2 \mathrm{eV}\left(3 \mathrm{~d}_{5 / 2}\right)$ corresponded to $\mathrm{Pd}(\mathrm{II})$ with binding energy exactly the same as in the primary form of palladium in $\mathrm{Pd}(\mathrm{OAc})_{2}$ (Figure 1a). The calculated content of $\mathrm{Pd}(0)$ present in the catalysts prepared at RT (C1) and at $80{ }^{\circ} \mathrm{C}(\mathrm{C} 2)$ was $20 \%$ and $45 \%$, respectively.

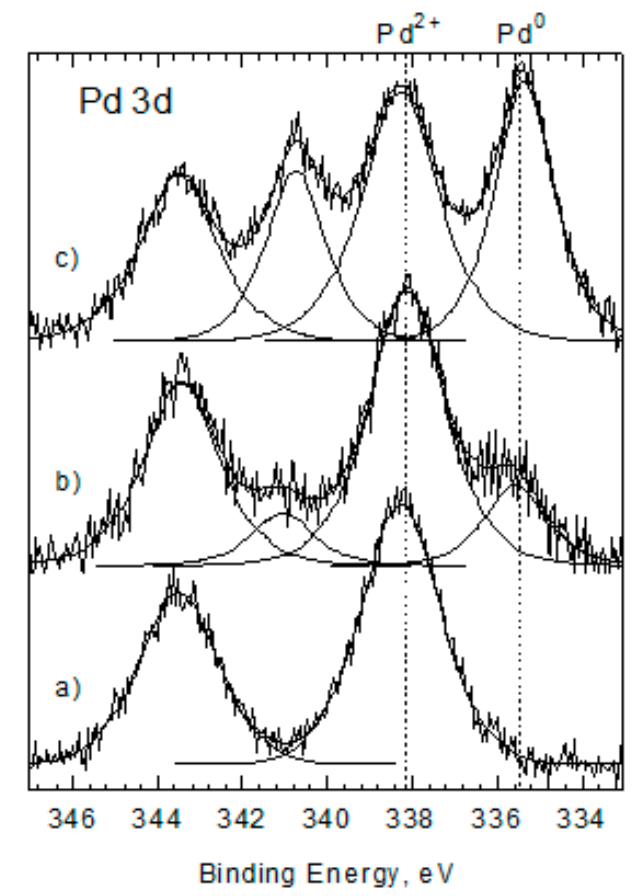

Figure 1. Pd $3 d$ core level spectra for $\mathrm{Pd}(\mathrm{OAc})_{2}$ as reference (a), $\mathrm{Pd} / \mathrm{DNA}(\mathrm{C} 1)$ prepared at $\mathrm{RT}(\mathbf{b})$, and Pd/DNA (C2) prepared at $80^{\circ} \mathrm{C}$ (c).

Figures 2 and 3 present $\mathrm{N} 1 \mathrm{~s}$ and $\mathrm{P} 2 \mathrm{p}$ spectra of $\mathrm{C} 1$ and $\mathrm{C} 2$. The binding energies, $\mathrm{BE} 132.89 \mathrm{eV}$ and $\mathrm{BE} 133.74 \mathrm{eV}$, were attributed to $\mathrm{P} 2 \mathrm{p}_{3 / 2}$ and $\mathrm{P} 2 \mathrm{p}_{1 / 2}$, respectively. These values are characteristic of $\mathrm{PO}_{4}{ }^{3-}$ of DNA. Similarly, the N 1s peak at $399.32 \mathrm{eV}$ was assigned to N-C bond in DNA. In both cases, the $\mathrm{N}$ 1s and $\mathrm{P} 2 \mathrm{p}$ signals, small chemical changes of $\mathrm{BE}$ values relative to pure DNA were 
observed after the introduction of Pd (Figures 2 and 3). The chemical shift of peaks increased with the increase in the $\mathrm{Pd}(0)$ content indicating the interaction of Pd NPs with the DNA surface. The observed shifts of Pd/DNA peaks to higher binding energy values were estimated for $\mathrm{C} 1$ and $\mathrm{C} 2$ and amounted to 0.3 and $0.5 \mathrm{eV}$ for $\mathrm{N} 1 \mathrm{~s}$ and to 0.2 and $0.4 \mathrm{eV}$ for P $2 \mathrm{p}$.

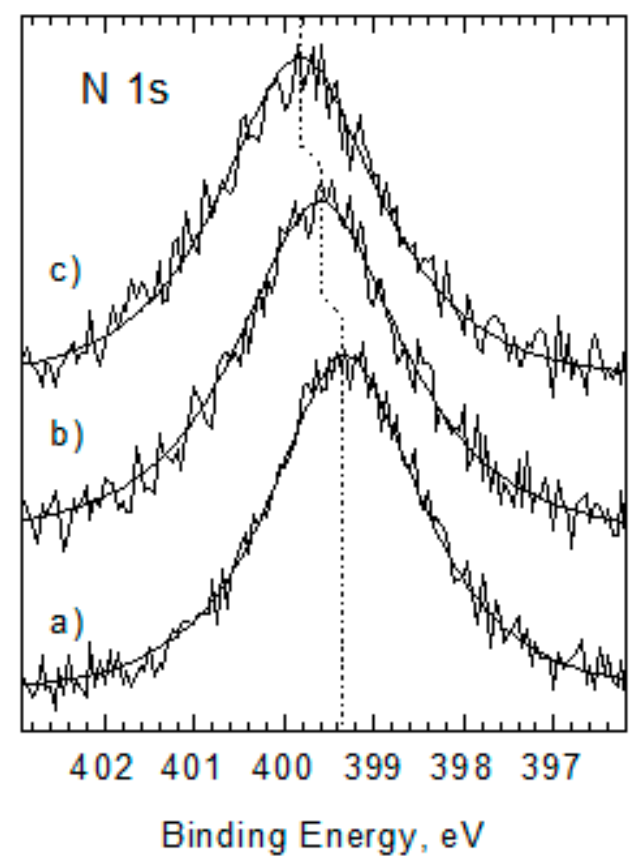

Figure 2. N 1s core level spectra for DNA surface (as reference) (a), Pd/DNA (C1) prepared at RT (b), and Pd/DNA (C2) prepared at $80^{\circ} \mathrm{C}$ (c).

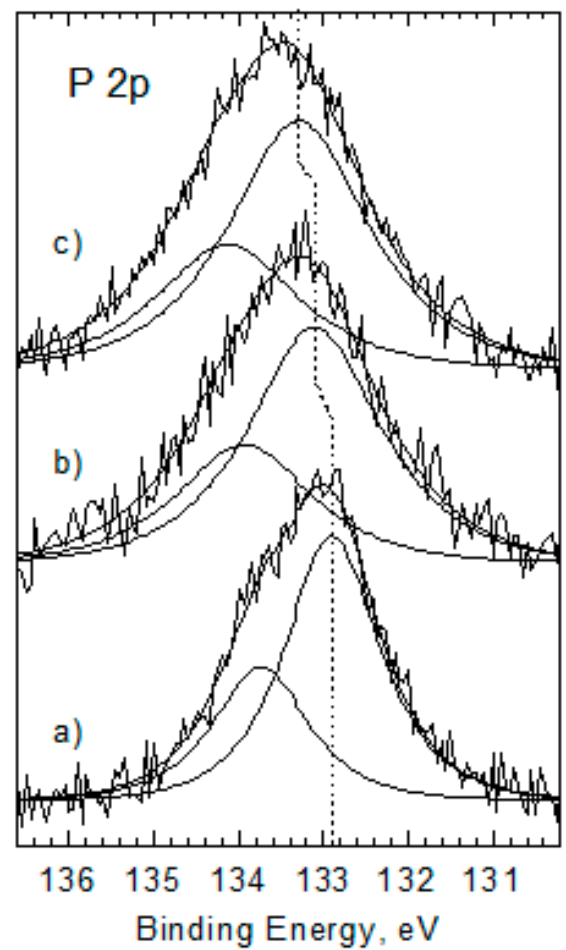

Figure 3. P $2 p$ core level spectra for DNA surface (as reference) (a), Pd/DNA (C1) prepared at RT (b), and Pd/DNA (C2) prepared at $80^{\circ} \mathrm{C}(\mathbf{c})$.

Figure 4 shows the Pd 3d spectra of C2 catalyst surface after Suzuki-Miyaura reaction. The optimal fit was obtained by assuming the presence of two palladium forms. The dominant component 
with binding energy of $335.0 \mathrm{eV}$ for $\operatorname{Pd}\left(3 \mathrm{~d}_{5 / 2}\right)$ was assigned to $\operatorname{Pd}(0)$. The amount of $\operatorname{Pd}(0)$ was estimated as $76.6 \%$ (Figure 4). The remaining part of the Pd $3 d$ spectrum was assigned to $\mathrm{Pd}(\mathrm{II})$ with peak at binding energy $337.8 \mathrm{eV}$. With deconvolution the $\mathrm{Pd}(0)$ peak asymmetry was taken into account [32]. The chemical shifts between $\mathrm{Pd}(0)$ and $\mathrm{Pd}(\mathrm{II})$ of $2.5-2.6 \mathrm{eV}$ were very similar to those shown in Figure 1 between the reduced $\mathrm{Pd}(0)$ in $\mathrm{C} 2$ and $\mathrm{Pd}(\mathrm{II})$ in $\mathrm{Pd}(\mathrm{OAc})_{2}$, what allows to formulate analogous conclusions. Slightly lower binding energies, $0.3-0.5 \mathrm{eV}$ can be explained by the inaccuracy in estimating the reference energy $\mathrm{C} 1 \mathrm{~s}$, due to the possible different proportions of $\mathrm{CC}$ bonds in the straight and ring chains or larger Pd dispersion after the reaction.

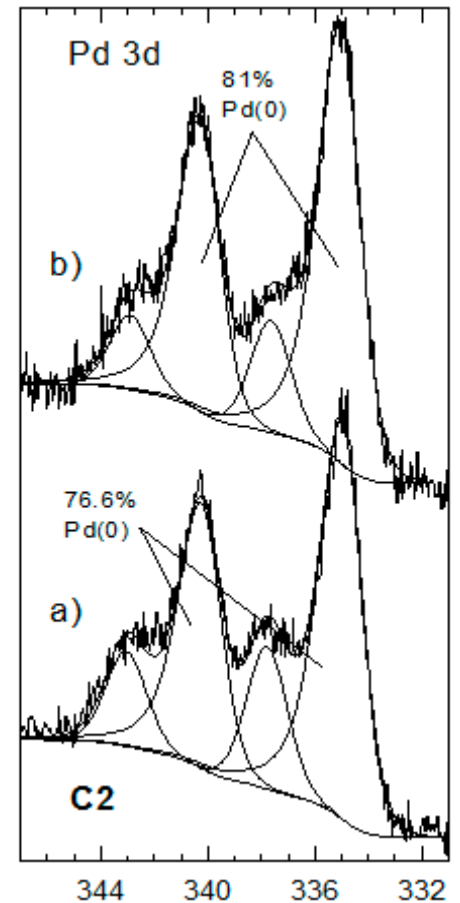

Figure 4. Pd 3d core level spectra for Pd/DNA (C2) recovered after the Suzuki-Miyaura reaction 'as received' form (a) and after smooth $\mathrm{Ar}^{+}$sputtering $\left(500 \mathrm{eV}, 1 \mathrm{~min}, 0.2 \mu \mathrm{A} / \mathrm{cm}^{2}+1 \mathrm{keV}, 1 \mathrm{~min}\right.$, $\left.1.3 \mu \mathrm{A} / \mathrm{cm}^{2}\right)(\mathbf{b})$.

The procedure used for recovering the 'powder' catalyst for analytical purposes of XPS required long-term contact with air at elevated temperature, hence on the surface of the metallic palladium also $\mathrm{PdO}$ could be present in addition to carbon contaminations and its oxidized forms $(\mathrm{CO}, \mathrm{C}=\mathrm{O})$. To solve this problem, the grain surfaces of the catalyst samples were cleaned with $\mathrm{Ar}+$ beam. To completely avoid the possible $\mathrm{Pd}(\mathrm{II})$ photoreduction, the second series $\mathrm{Ar}+$ sputtering was performed, with very mild etching: I-500 eV, $1 \mathrm{~min}, 0.2 \mu \mathrm{A} / \mathrm{cm}^{2}$ and II-1 keV, $1 \mathrm{~min}, 1.3 \mu \mathrm{A} / \mathrm{cm}^{2}$. It turned out that as a result, contribution of $\operatorname{Pd}(0)$ increased to $81 \%$.

The performed X-ray photoelectron spectroscopy (XPS) studies evidenced increase of $\operatorname{Pd}(0)$ amount in catalyst $\mathrm{C} 2$ from ca. $45 \%$ at the beginning to ca. $81 \%$ in the end of catalytic reaction. Thus, $\mathrm{Pd}(\mathrm{II})$ was reduced in situ forming catalytically active $\mathrm{Pd}(0)$ as $\mathrm{Pd}(0)$ nanoparticles. Identification of $\operatorname{Pd}(0)$ nanoparticles was based on XRD and TEM analyses.

Typical XRD diffractogram of C2 reveal several well-defined peaks. These peaks are attributed to $\operatorname{Pd}(0)$ crystallizing in the Fm3m space group (JCPDS card number 5-681). Broadening of the diffraction lines indicated small size of Pd NPs (Figure 5). The XRD picture obtained for C2 catalyst recovered after the Suzuki-Miyaura reaction was very similar and indicated that the size of Pd NPs did not change (Figure 5). 


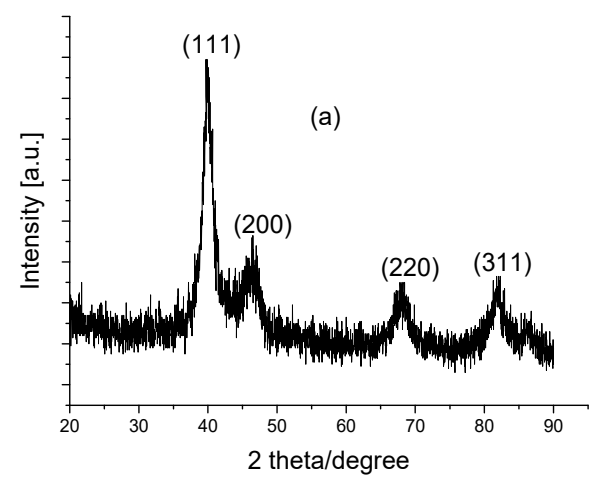

(a)

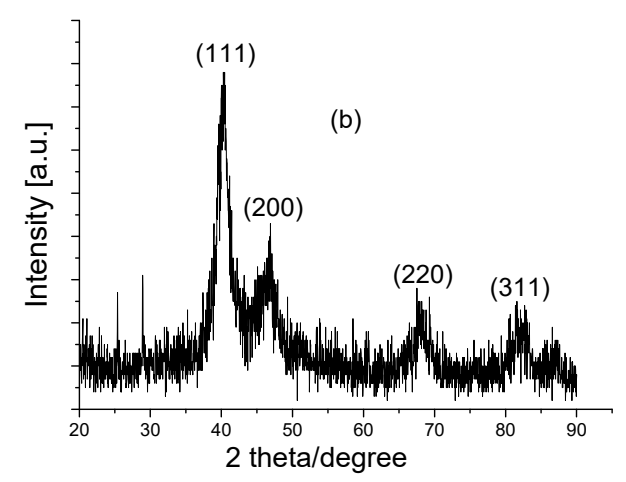

(b)

Figure 5. XRD patterns of C2 (a), and C2 recovered after the Suzuki-Miyaura reaction (b).

TEM studies were carried out to get deeper insight into characteristics of the Pd/DNA samples. First, the catalyst $\mathrm{C} 1$ obtained at room temperature was analyzed. A wide range of nanoparticle sizes (3-25 nm) was observed with a maximum of ca. 13-15 nm, together with some aggregates (Figure 6).
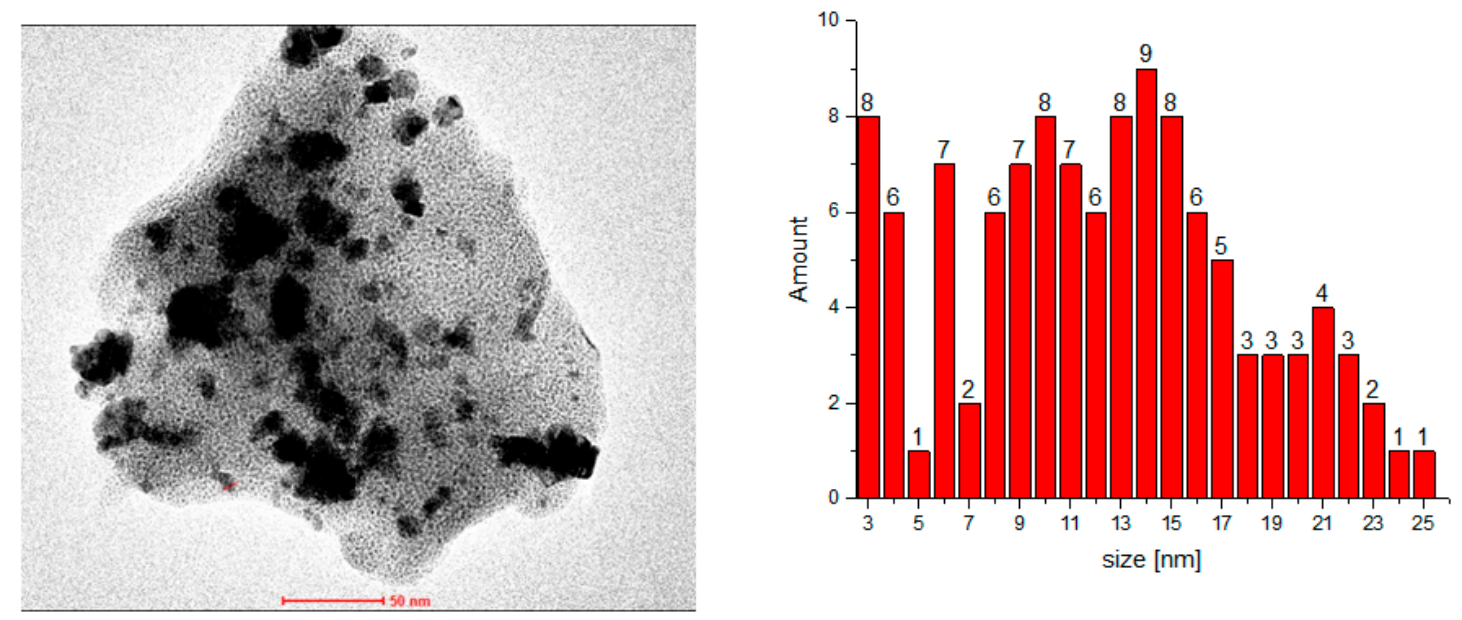

Figure 6. Morphology and size distribution of C1 Pd/DNA [33].

The second sample, $\mathrm{C} 2$, was prepared from DNA and $\mathrm{Pd}(\mathrm{OAc})_{2}$ stirred within the $\mathrm{H}_{2} \mathrm{O} / \mathrm{EtOH}$ mixed solvent system for $2 \mathrm{~h}$ at $80^{\circ} \mathrm{C}$. As the temperature rose from room temperature to $80^{\circ} \mathrm{C}$, smaller nanoparticles were formed. In addition, some nanoparticles took a cylinder shape (Figure 7).
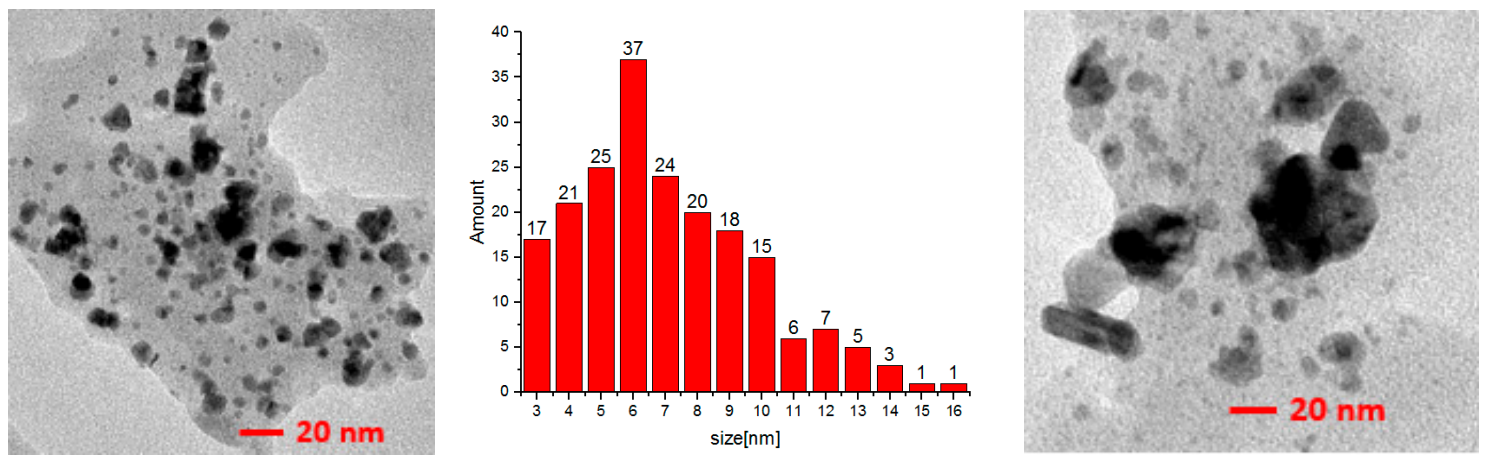

Figure 7. Morphology and size distribution of C2 Pd/DNA.

The next synthetic method was different from the previous one in only one respect. The amount of $\mathrm{Pd}(\mathrm{OAc})_{2}$ used for the preparation of $\mathrm{C} 3 \mathrm{Pd} / \mathrm{DNA}$ was reduced by half (to $56 \mathrm{mg}$ ). Interestingly, 
this resulted in a decrease in the Pd NP size to $4-7 \mathrm{~nm}$, and the size distribution became narrower (Figure 8).
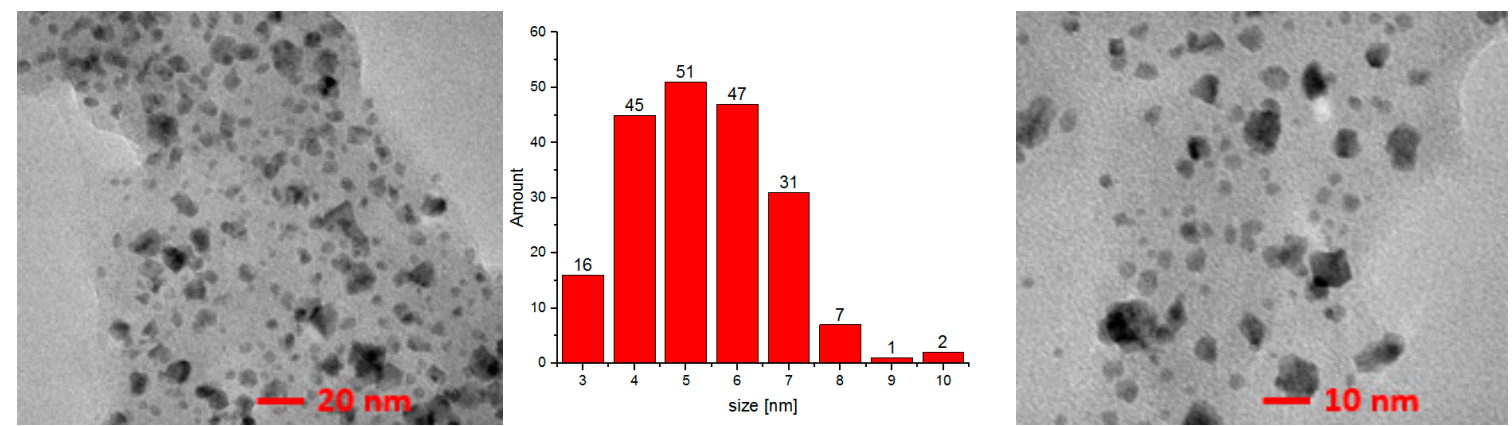

Figure 8. Morphology and size distribution of C3 Pd/DNA.

When $\mathrm{PdCl}_{2}$ was used instead of $\mathrm{Pd}(\mathrm{OAc})_{2}$ for the preparation of $\mathrm{C} 4 \mathrm{Pd} / \mathrm{DNA}$, nanoparticles of well-defined shapes were obtained. In Figure 9, nanoparticles prepared in this manner appear in triangular, cubic, and unidentified shapes. The size of most of the nanoparticles ranged between 9 and $12 \mathrm{~nm}$ (Figure 9).
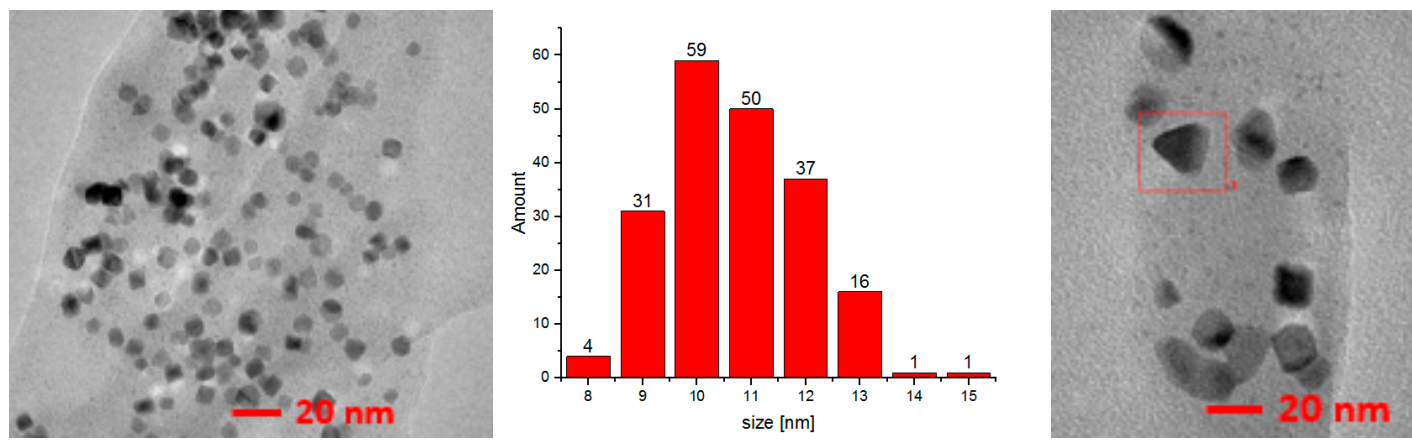

Figure 9. Morphology and size distribution of C4 Pd/DNA.

A TEM micrograph of C4 recovered after the Suzuki-Miyaura reaction showed some aggregates, but there were still plenty of well-dispersed nanoparticles. Interestingly, their shapes were identical to those before the reaction, for instance triangular (Figure 10).
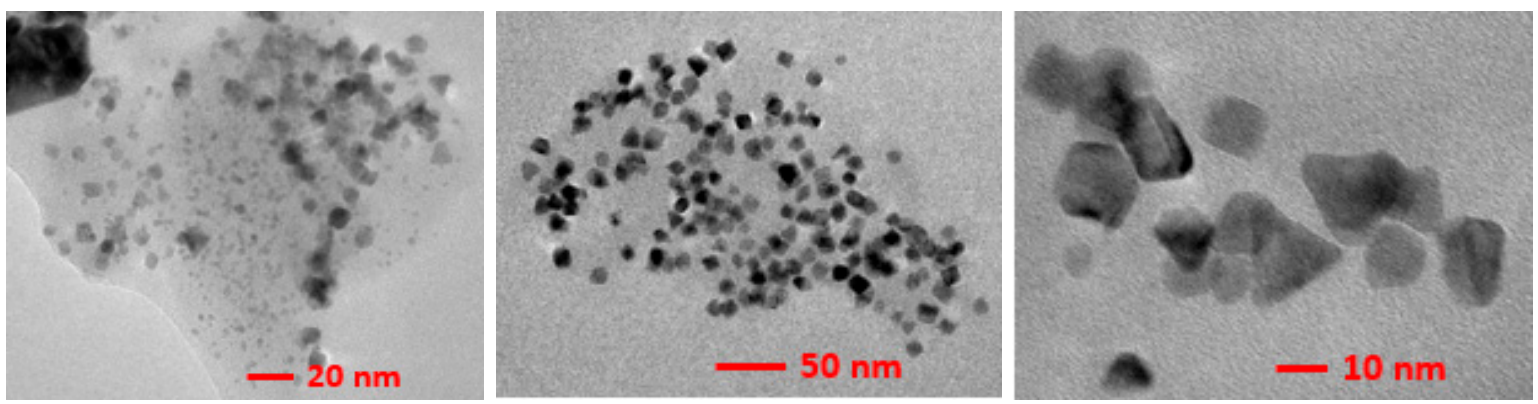

Figure 10. Morphology of C4 Pd/DNA recovered after the Suzuki-Miyaura reaction.

\subsection{Suzuki-Miyaura Cross-Coupling Reaction}

Under optimized conditions (Table S1), Pd/DNA catalysts $\mathrm{C} 1-\mathrm{C} 4$, were tested in the Suzuki-Miyaura reaction of three different aryl bromides with phenylboronic acid (Scheme 1, Table 1). 


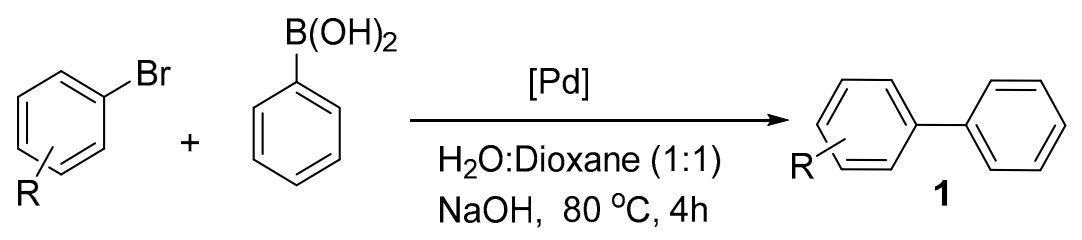

Scheme 1. Suzuki-Miyaura coupling of aryl bromides catalyzed by C1-C4.

Table 1. The Suzuki-Miyaura coupling of various aryl bromides and phenylboronic acid catalyzed by the catalysts $\mathrm{C} 1-\mathrm{C} 4{ }^{\mathrm{a}}$.

\begin{tabular}{cccc}
\hline Entry & [Pd] & $\mathbf{R}$ & Yield 1 $^{\mathbf{b}} \mathbf{( \% )}$ \\
\hline 1 & Pd/DNA (C1) & $2-\mathrm{OCH}_{3}$ & 83 \\
2 & Pd/DNA (C2) & $2-\mathrm{OCH}_{3}$ & 77 \\
3 & Pd/DNA (C3) & $2-\mathrm{OCH}_{3}$ & 74 \\
4 & Pd/DNA (C4) & $2-\mathrm{OCH}_{3}$ & 64 \\
5 & Pd/DNA (C1) & $2-\mathrm{Me}$ & 73 \\
$6^{\mathrm{c}}$ & Pd/DNA (C1) & $2-\mathrm{Me}$ & 58 \\
7 & Pd/DNA (C2) & $2-\mathrm{Me}$ & 75 \\
8 & Pd/DNA (C3) & $2-\mathrm{Me}$ & 64 \\
9 & Pd/DNA (C4) & $2-\mathrm{Me}$ & 59 \\
10 & Pd/DNA (C1) & $4-\mathrm{Me}$ & 85 \\
11 & Pd/DNA (C2) & $4-\mathrm{Me}$ & 75 \\
12 & Pd/DNA (C3) & $4-\mathrm{Me}$ & 70 \\
13 & Pd/DNA (C4) & $4-\mathrm{Me}$ & 54 \\
\hline
\end{tabular}

a $[\mathrm{Pd}](1 \mathrm{~mol} \%), \mathrm{NaOH}(1.2 \mathrm{mmol})$, dioxane/water (1:1) $(5 \mathrm{~mL})$, aryl halide (1 mmol), phenylboronic acid (1.2 mmol), $80{ }^{\circ} \mathrm{C}, 4 \mathrm{~h} .{ }^{\mathrm{b}}$ Yields were determined by (GC) using dodecane as an internal standard. ${ }^{\mathrm{c}} 50{ }^{\circ} \mathrm{C}, 12 \mathrm{~h}$.

Surprisingly, the catalyst $\mathrm{C} 1$, containing only $20 \%$ of $\operatorname{Pd}(0)$ as relatively big nanoparticles, gave the best conversion of 2-bromoanisole and 4-bromotoluene (Table 1, entries 1 and 10). In reaction of 2-bromotoluene, $\mathrm{C} 1$ and $\mathrm{C} 2$ gave similar results, 73 and 75\%, respectively (Table 1, entries 5 and 7). Catalysts C2 and C3 which have similar morphologies, differ in activity and C3 gave lower conversion in all cases. However, the catalyst C4, which contained slightly bigger nanoparticles than C2 and C3, provided a conversion of 54-64\% only (Table 1). Thus, catalytic activity cannot be directly correlated with nanoparticle size.

It can, therefore, be assumed that the most active catalyst was formed in situ from $\mathrm{Pd}(\mathrm{II})$ under catalytic reaction conditions. In our previous studies, we observed a similar phenomenon for $\mathrm{Pd} / \mathrm{Al}_{2} \mathrm{O}_{3}$ [34] or Pd supported on glicydyl methacrylate polymer (GMA-CHDA) [35], which formed active $\mathrm{Pd}(0)$ from $\mathrm{Pd}(\mathrm{II})$ during the Suzuki reaction. The activity of these in situ formed Pd NPs was higher than that of pre-made ones [34,35]. The similar activity of $\mathrm{C} 1$ and $\mathrm{C} 2$ catalysts, containing different amounts of $\operatorname{Pd}(0)$ nanoparticles, indicated on the relatively fast reduction of $\operatorname{Pd}(\mathrm{II})$ to $\mathrm{P}(0)$ under catalytic conditions.

The substrate scope was next surveyed applying catalyst C2 (Scheme 2, Table 2).

$$
\begin{gathered}
\mathrm{Ar}_{1}-\mathrm{Br}+\mathrm{Ar}_{2} \mathrm{~B}(\mathrm{OH})_{2} \frac{\mathrm{C} 2}{\stackrel{\mathrm{H}}{\mathrm{H} \mathrm{O} \text { :Dioxane }(1: 1)} \mathrm{AaOH}, 80^{\circ} \mathrm{C}, 4 \mathrm{~h}} \\
\mathrm{NaO}-\mathrm{Ar}_{2}
\end{gathered}
$$

Scheme 2. Substrate scope in the Suzuki-Miyaura coupling. 
Table 2. Substrate scope in the Suzuki-Miyaura coupling catalyzed by $\mathrm{C} 2{ }^{\mathrm{a}}$.

\begin{tabular}{|c|c|c|c|}
\hline Entry & $\mathrm{Ar}_{1}$ & $\mathrm{Ar}_{2}$ & Yield 1 b (\%) \\
\hline 1 & $2-\mathrm{Cl}-\mathrm{C}_{6} \mathrm{H}_{4}$ & $\mathrm{Ph}$ & 81 \\
\hline 2 & $3-\mathrm{Cl}-\mathrm{C}_{6} \mathrm{H}_{4}$ & $\mathrm{Ph}$ & 95 \\
\hline 3 & $4-\mathrm{Cl}-\mathrm{C}_{6} \mathrm{H}_{4}$ & $\mathrm{Ph}$ & $92(91)^{c}$ \\
\hline 4 & $4-\mathrm{NO}_{2}-\mathrm{C}_{6} \mathrm{H}_{4}$ & $\mathrm{Ph}$ & 93 \\
\hline 5 & $4-\mathrm{CHO}-\mathrm{C}_{6} \mathrm{H}_{4}$ & $\mathrm{Ph}$ & $95(90)^{c}$ \\
\hline 6 & $2-\mathrm{CH}_{3} \mathrm{O}-\mathrm{C}_{6} \mathrm{H}_{4}$ & $\mathrm{Ph}$ & 77 \\
\hline 7 & $4-\mathrm{CH}_{3} \mathrm{O}-\mathrm{C}_{6} \mathrm{H}_{4}$ & $\mathrm{Ph}$ & 64 \\
\hline 8 & $2-\mathrm{CH}_{3}-\mathrm{C}_{6} \mathrm{H}_{4}$ & $\mathrm{Ph}$ & 79 \\
\hline 9 & $4-\mathrm{CH}_{3}-\mathrm{C}_{6} \mathrm{H}_{4}$ & $\mathrm{Ph}$ & 73 \\
\hline 10 & $2-\mathrm{CN}-\mathrm{C}_{6} \mathrm{H}_{4}$ & $\mathrm{Ph}$ & $85(70)^{c}$ \\
\hline 11 & $4-\mathrm{CN}-\mathrm{C}_{6} \mathrm{H}_{4}$ & $\mathrm{Ph}$ & 84 \\
\hline 12 & $4-\mathrm{COCH}_{3}-\mathrm{C}_{6} \mathrm{H}_{4}$ & $\mathrm{Ph}$ & 95 \\
\hline 13 & $\mathrm{Ph}$ & $\mathrm{Ph}$ & $94(89)^{c}$ \\
\hline 14 & $2-\mathrm{CH}_{3}-\mathrm{C}_{6} \mathrm{H}_{4}$ & 4- $\mathrm{CH}_{3}$-1-naph & $64(52)^{c}$ \\
\hline 15 & $2-\mathrm{CH}_{3}-\mathrm{C}_{6} \mathrm{H}_{4}$ & 1-naph & 72 \\
\hline 16 & $\mathrm{Ph}$ & $3-\mathrm{BnO}-\mathrm{C}_{6} \mathrm{H}_{4}$ & 80 \\
\hline 17 & $\mathrm{Ph}$ & $3-\mathrm{CF}_{3}-\mathrm{C}_{6} \mathrm{H}_{4}$ & 83 \\
\hline 18 & $\mathrm{Ph}$ & $4-\mathrm{COCH}_{3}-\mathrm{C}_{6} \mathrm{H}_{4}$ & $87(80)^{c}$ \\
\hline 19 & $\mathrm{Ph}$ & 1-naph & 87 \\
\hline 20 & $\mathrm{Ph}$ & 4- $\mathrm{CH}_{3}-1$-naph & 84 \\
\hline 21 & $\mathrm{Ph}$ & $\left(\mathrm{CH}_{3}\right)_{3} \mathrm{C}-\mathrm{C}_{6} \mathrm{H}_{4}$ & 89 \\
\hline 22 & 1,3-dimethyl- $\mathrm{C}_{6} \mathrm{H}_{3}$ & $\mathrm{Ph}$ & $33(15)^{d}$ \\
\hline 23 & $\mathrm{Ph}$ & 1,3-dimethyl- $\mathrm{C}_{6} \mathrm{H}_{3}$ & trace $(\text { trace })^{\mathrm{d}}(14)^{\mathrm{e}}$ \\
\hline 24 & $\mathrm{Ph}$ & 1,3-dimethoxy- $\mathrm{C}_{6} \mathrm{H}_{3}$ & 0 \\
\hline 25 & 3-Py & $\mathrm{Ph}$ & 42 \\
\hline 26 & pyrimidine & $\mathrm{Ph}$ & 62 \\
\hline
\end{tabular}

a [Pd] (1 mol\%), NaOH (1.2 mmol), dioxane/water (1:1) $(5 \mathrm{~mL})$, aryl halide $(1 \mathrm{mmol})$, arylboronic acid (1.2 mmol), $80{ }^{\circ} \mathrm{C}, 4 \mathrm{~h}$. ${ }^{\mathrm{b}}$ Yields were determined by (GC) using dodecane as an internal standard. ${ }^{\mathrm{c}}$ Isolated yield. ${ }^{\mathrm{d}} \mathrm{C} 1 \mathrm{was}$ used instead of $\mathrm{C} 2 .{ }^{\text {e }} 100{ }^{\circ} \mathrm{C}, 4 \mathrm{~h}$.

For this purpose, reactions were first carried out between phenylboronic acid and bromobenzene derivatives. Meta-, para-, and ortho-chloro-bromobenzenes were tested as substrates (Table 2, entries 1,2 and 3). As for the activities depending on the position of substituents the highest yield was obtained with $m$-chloro-bromobenzene (Table 2, entry 2 ). While good yield was obtained with $p$-chloro-bromobenzene the yield was lower with $o$-chloro-bromobenzene (Table 2, entries 1 and 3 ). Under these conditions only the $\mathrm{C}-\mathrm{Br}$ bond was activated, while $\mathrm{C}-\mathrm{Cl}$ remained unchanged. The high yield was noted when an electron-withdrawing substituent was present at the para position of bromobenzene (Table 2, entries 4, 5, 11 and 12). Other substituents promoted lower yield, up to $79 \%$. Among the reactions conducted with phenylboronic acid derivatives, the best conversion was obtained with phenylboronic acid (Table 2, entry 13). When electron-withdrawing and electron-donating groups were present at the para position of phenylboronic acid, yields were close to one another (Table 2, entries 18 and 21) and increased to $80-89 \%$. As expected, in reactions conducted with bulky bromobenzene and aryl boronic acid derivatives, lower yields of products were obtained (Table 2, entries 22, 23 and 24). While in reaction conducted with 3-bromopyridine low yield of product was obtained, the yield was modest with 5-bromopyrimidine (Table 2, entries 25 and 26).

\subsection{Catalyst Recycling in Suzuki-Miyaura Reaction}

Recyclability is one of the desired properties of supported catalysts [36]. The recycling potential of $\mathrm{Pd} / \mathrm{DNA}$ was therefore investigated. For this purpose, a reaction was implemented between 4-bromobenzaldehyde and phenylboronic acid with $1 \mathrm{~mol} \%$ and $0.5 \mathrm{~mol} \%$ of Pd. At the end of the catalytic reaction, the organic products were separated by extraction, and the catalyst was recovered for the next run by simple phase separation. After the first run, the palladium content in the reaction 
solution was determined as $0.152 \mathrm{ppm}$. Such a low amount of palladium evidenced its negligible leaching from the DNA support. In our study, Pd/DNA was recycled for seven consecutive runs with $1 \mathrm{~mol} \%$ of Pd (Figure 11) and five consecutive runs with $0.5 \mathrm{~mol} \%$ of Pd (Figure 11). Although some conversion decrease was observed during recycling, the stability of Pd/DNA, at least in five runs, was quite satisfactory.
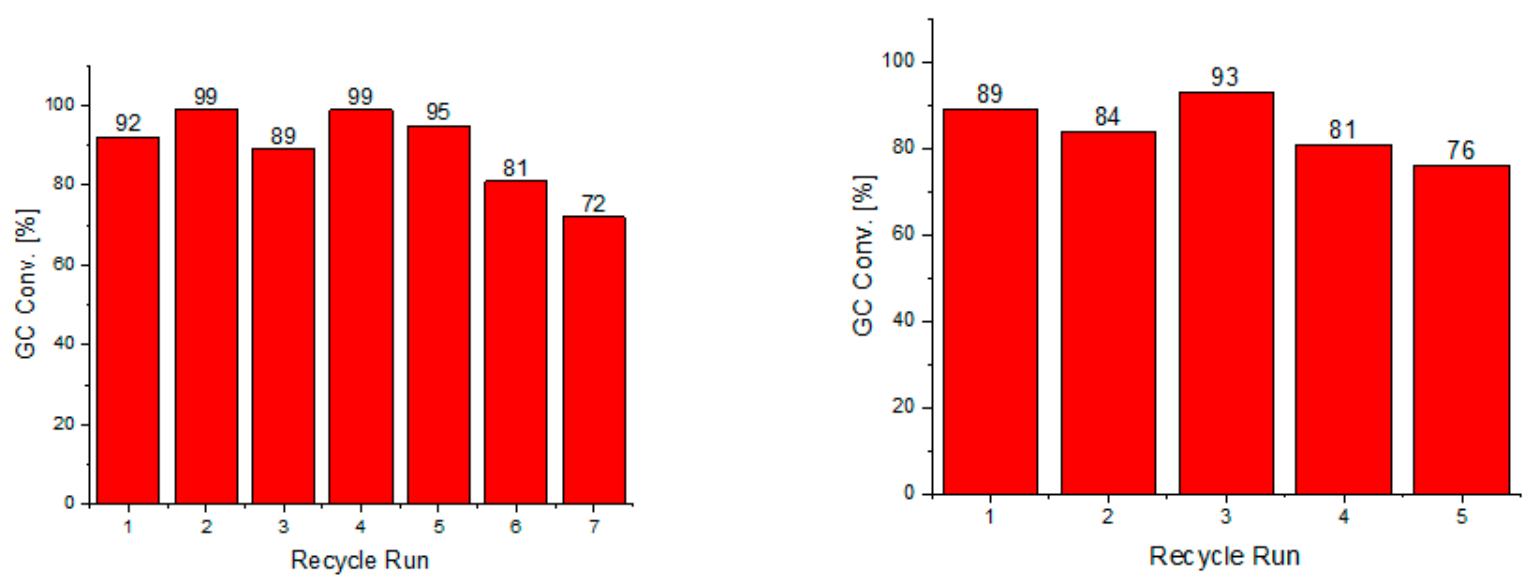

Figure 11. Recycling of C2; (left) $1 \mathrm{~mol} \%$ of Pd, (right) $0.5 \mathrm{~mol} \%$ of Pd.

The TEM analysis of the catalyst $\mathrm{C} 2$ recovered at the end of the recycling experiment showed some increase in the average diameter of Pd NPs, with the maximum at ca. 9-10 nm, but without significant agglomeration (Figure 12).
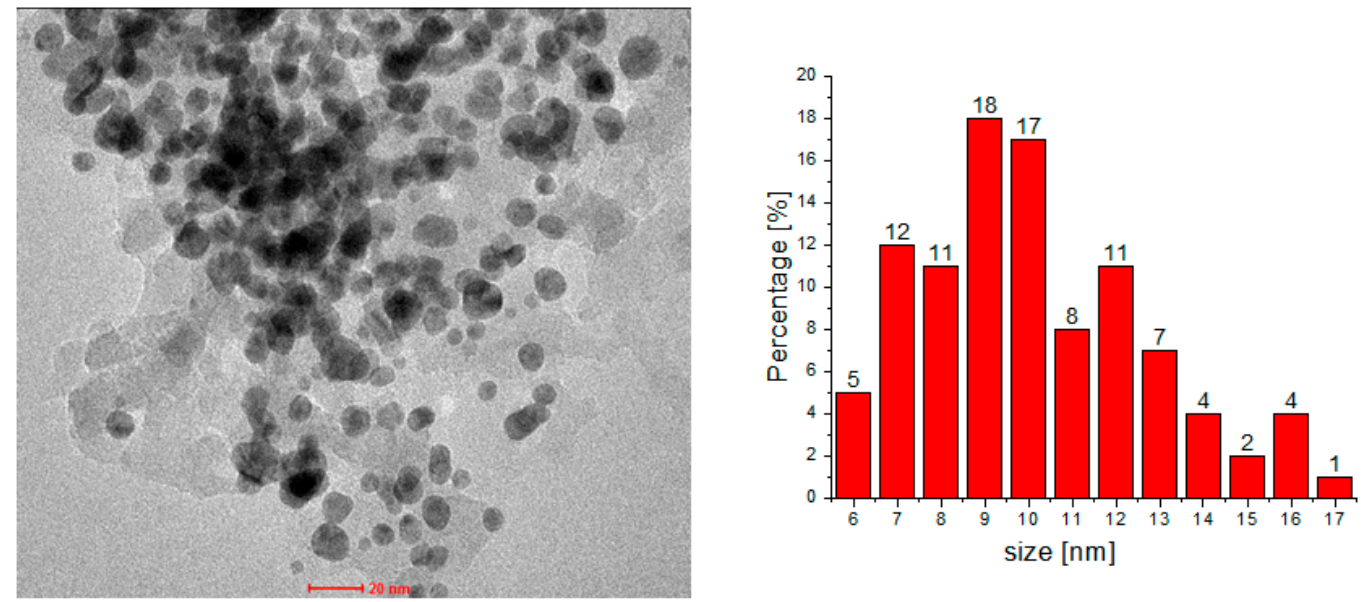

Figure 12. TEM images of $\mathrm{C} 2$ after seven catalytic runs and particle size distribution [33].

The activity of the solution remaining after the separation of Pd/DNA from the reaction mixture was also studied. Thus, the Suzuki-Miyaura reaction of 2-bromotoluene with phenylboronic acid catalyzed by Pd/DNA was stopped after $30 \mathrm{~min}$, and the reaction solution was subjected to hot filtration through Celite. The as-obtained filtrate was next re-heated for $3.5 \mathrm{~h}$ at $80{ }^{\circ} \mathrm{C}$. After that time the GC analysis showed $40 \%$ conversion of 2-bromotoluene, which was comparable to that obtained after $30 \mathrm{~min}$ of the standard reaction (32\%, Figure 13) and significantly lower than that noted after $4 \mathrm{~h}$ (75\%, Figure 13). This result indicated a heterogeneous reaction pathway, in agreement with the good recyclability of $\mathrm{Pd} / \mathrm{DNA}$ and the insignificant level of palladium leaching. 


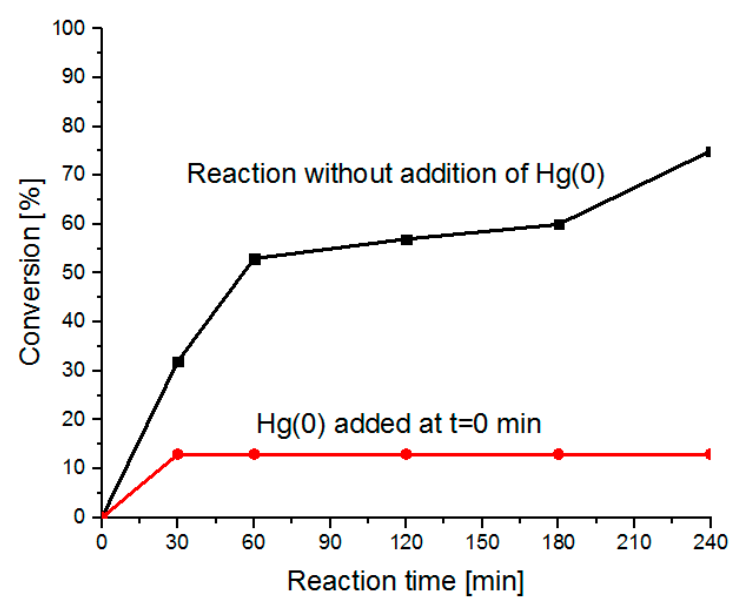

Figure 13. Suzuki-Miyaura reaction of 2-bromotoluene in the presence of $\mathrm{Hg}(0)$.

\subsection{Treatment of $\mathrm{C} 2$ with $\mathrm{Hg}(0)$}

The above-reported results made it possible to propose a heterogeneous reaction pathway with the performance of the catalytic reaction on the surface of Pd NPs supported on DNA. In order to confirm this assumption, the catalytic reaction was performed in the presence of an $\mathrm{Hg}(0)$ inhibitor which can amalgamate Pd NPs, blocking their activity [37-39]. When $\mathrm{Hg}(0)$ was added to the catalytic system together with the substrates, the conversion of 2-bromotoluene was $13 \%$ (Table 3, entry 2 ). When $\operatorname{Hg}(0)$ was added 30 min later, the conversion was 53\% (Table 3, entry 3). Thus, the presence of $\mathrm{Hg}(0)$ resulted in decrease of the reaction yield.

Table 3. Suzuki-Miyaura reaction of 2-bromotoluene with phenylboronic acid catalyzed by Pd/DNA

(C2) in the presence of $\mathrm{Hg}(0)^{\mathrm{a}}$.

\begin{tabular}{ccc}
\hline Entry & Poison Additive & GC Conv. [\%] \\
\hline 1 & None & 75 \\
2 & Hg added at the begining of the reaction & 13 \\
3 & Hg added after 30 min & 53 \\
\hline
\end{tabular}

a $[\mathrm{Pd}](1 \mathrm{~mol} \%), \mathrm{NaOH}(1.2 \mathrm{mmol})$, dioxane/water (1:1) $(5 \mathrm{~mL}), 2$-bromotoluene $(1 \mathrm{mmol})$, phenylboronic acid $(1.2 \mathrm{mmol}), 80^{\circ} \mathrm{C}, 4 \mathrm{~h},[\mathrm{Hg}] /[\mathrm{Pd}]=500$.

The SEM image of the catalyst $\mathrm{C} 2$ treated with $\mathrm{Hg}(0)$ is presented in Figure 14 together with EDX analyses performed at four points to estimate the $\mathrm{Pd} / \mathrm{Hg}$ ratios. Importantly, both elements were found in the same places and the $\mathrm{Hg} / \mathrm{Pd}$ ratios calculated from the weight \% varied from 1.14 to 0.44 . At three points, the amount of $\mathrm{Hg}$ was found higher than the amount of Pd (Figure 14). Presumably, a Pd-Hg amalgam (alloy) was formed during the catalytic reaction on the surface of DNA. That is why the catalytic activity of the catalyst decreased remarkably when $\mathrm{Hg}(0)$ was present. The similar effect was also observed for the catalyst $\mathrm{Pd} / \mathrm{Al}_{2} \mathrm{O}_{3}$ [40]. 


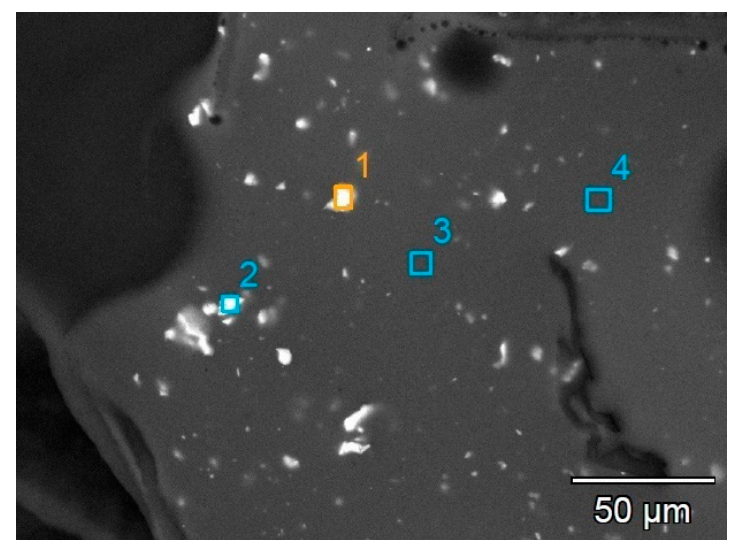

Figure 14. SEM image of C2 Pd/DNA after the Suzuki-Miyaura reaction with $\mathrm{Hg}(0) . \mathrm{Pd} / \mathrm{Hg}$ : $1-1.14$; $2-0.91 ; 3-0.87 ; 4-0.44$.

\subsection{Carbonylative Couplings}

Interesting results with Pd/DNA obtained in the Suzuki-Miyaura reaction encouraged us to test its catalytic activity for the first time in carbonylative coupling.

The carbonylative Suzuki coupling was studied using the catalyst C1. For this purpose, the coupling of iodobenzene (PhI) and phenylboronic acid $\left(\mathrm{PhB}(\mathrm{OH})_{2}\right)$ carried out under $\mathrm{CO}$ atmosphere was selected as a model reaction (Scheme 3, Table 4). Regardless of all attempts to optimize the conditions, only a limited amount of benzophenone, max. $35 \%$, could be produced in this system (also see Table S3).<smiles>O=C(O)c1ccc(-c2ccc(-c3ccc(C(=O)c4ccc(-c5ccc(O)cc5)cc4)cc3)cc2)cc1</smiles>

Scheme 3. Carbonylative Suzuki coupling.

Table 4. Carbonylative Suzuki coupling catalyzed by C1: solvent, base and CO pressure testing a .

\begin{tabular}{ccccccc}
\hline Entry & Solvent & Base & Conv. $^{\mathbf{b}} \mathbf{( \% )}$ & Yield 2 $^{\mathbf{b}}$ & Yield 3 $^{\mathbf{b}}$ & Yield 4 $^{\mathbf{b}}$ \\
\hline 1 & $\mathrm{H}_{2} \mathrm{O}$ & $\mathrm{NEt}_{3}$ & 88 & 25 & 41 & 22 \\
2 & $\mathrm{IPA} / \mathrm{H}_{2} \mathrm{O}(1 / 1)$ & $\mathrm{NaHCO}_{3}$ & 100 & 34 & 38 & 28 \\
3 & Dioxane $/ \mathrm{H}_{2} \mathrm{O}(1 / 1)$ & $\mathrm{NaHCO}_{3}$ & 100 & 26 & 55 & 19 \\
$4^{\mathrm{c}}$ & Dioxane $/ \mathrm{H}_{2} \mathrm{O}(1 / 1)$ & $\mathrm{NaHCO}_{3}$ & 24 & 0 & 0 & 24 \\
5 & Dioxane $/ \mathrm{H}_{2} \mathrm{O}(4 / 1)$ & $\mathrm{K}_{3} \mathrm{PO}_{4}$ & 80 & 29 & 20 & 31 \\
6 & Anisole & $\mathrm{K}_{2} \mathrm{CO}_{3}$ & 0 & 0 & 0 & 0 \\
$7^{\mathrm{d}}$ & Anisole & $\mathrm{K}_{2} \mathrm{CO}_{3}$ & 0 & 0 & 0 & 0 \\
$8^{\mathrm{d}}$ & Anisole $/ \mathrm{H}_{2} \mathrm{O}(9 / 1)$ & $\mathrm{K}_{2} \mathrm{CO}_{3}$ & 66 & 35 & 31 & 0 \\
\hline
\end{tabular}

${ }^{\mathrm{a}}$ [Pd] $(1 \mathrm{~mol} \%)$, base $(1.2 \mathrm{mmol})$, solvent $(5 \mathrm{~mL})$, iodobenzene $(1 \mathrm{mmol})$, phenylboronic acid $(1.2 \mathrm{mmol}), 80{ }^{\circ} \mathrm{C}, \mathrm{CO}$ (balloon pressure), 4 h. ${ }^{\mathrm{b}}$ Conversion and yield were determined by (GC) using mesitylene as an internal standard. c 5 bar, $80^{\circ} \mathrm{C}, 4 \mathrm{~h} .{ }^{\mathrm{d}} 100^{\circ} \mathrm{C}, \mathrm{K}_{2} \mathrm{CO}_{3}(3 \mathrm{mmol})$, phenylboronic acid $(2 \mathrm{mmol})$.

However, another carbonylation product, benzoic acid (4), was formed under these conditions in amount up to $31 \%$. Interestingly, isopropyl benzoate was not obtained in reaction performed in IPA $/ \mathrm{H}_{2} \mathrm{O}$ (Table 4, entry 2). It was different than in the previously studied system which produced preferably ester but not acid under $\mathrm{CO}$ atmosphere [41]. Moreover, an increase of $\mathrm{CO}$ pressure even increased selectivity to benzoic acid, most probably due to the additional influence of the DNA. Also, the choice of solvent greatly affected the yield of carbonylative Suzuki coupling. In reactions carried out in pure organic solvents no conversion was obtained (Table 4, entries 6 and 7, also see Table S3). This can be explained by poor solubility of Pd/DNA in organic solvents. In Suzuki carbonylation 
conducted with bromobenzene no conversion was obtained. In reactions carried out without phenyl boronic acid, with iodobenzene benzoic acid was obtained but bromobenzene was not converted [33].

\section{Experimental}

All chemicals were purchased commercially and used without further purification. Fish sperm DNA (CAS:438545-06-3) was purchased from Sigma-Aldrich (St. Louis, MO, USA).

\subsection{Preparation of $P d / D N A(C 1, C 2, C 3, C 4)$}

In order to prepare Pd/DNA, four different methods were applied. While in methods 1-3 $\mathrm{Pd}(\mathrm{OAc})_{2}$ was used as the source of palladium, in method $4 \mathrm{PdCl}_{2}$ was used. Ambient temperature was used in method 1 and $80^{\circ} \mathrm{C}$ in methods $2-4$.

Method 1 (C1) [33]: $50 \mathrm{mg}$ of fish sperm DNA was dissolved in $5 \mathrm{~mL}$ of water. Then, $112 \mathrm{mg}$ of $\mathrm{Pd}(\mathrm{OAc})_{2}$ and $5 \mathrm{~mL}$ of ethanol were added in turn. The combined solution was stirred for $24 \mathrm{~h}$ at room temperature. During the reaction, the mixture changed in color from brown to black. Then with the aid of centrifugation at $7000 \mathrm{r} / \mathrm{min}, \mathrm{Pd} / \mathrm{DNA}$ was precipitated. The clear solution was poured out, and Pd/DNA was washed with acetone and dried in vacuo. Pd/DNA (C1) was obtained as a dark powder. (Pd target loading: $3.56 \mathrm{mmol} / \mathrm{g}$ ).

Method 2 (C2): $50 \mathrm{mg}$ of fish sperm DNA was dissolved in $5 \mathrm{~mL}$ of water. Then, $112 \mathrm{mg}$ of $\mathrm{Pd}(\mathrm{OAc})_{2}$ and $5 \mathrm{~mL}$ of ethanol were added in turn. The combined solution was stirred for $2 \mathrm{~h}$ at $80^{\circ} \mathrm{C}$. During heating, the mixture changed in color from brown to black. Finally, after cooling down to ambient temperature, Pd/DNA was precipitated. Then, by direct decantation, the clear solution was poured out, and Pd/DNA was washed with acetone and dried in vacuo. Pd/DNA (C2) was obtained as a dark powder. (Pd target loading: $3.61 \mathrm{mmol} / \mathrm{g}$ ).

Method 3 (C3): $50 \mathrm{mg}$ of fish sperm DNA was dissolved in $5 \mathrm{~mL}$ of water. Then, $56 \mathrm{mg}$ of $\mathrm{Pd}(\mathrm{OAc})_{2}$ and $5 \mathrm{~mL}$ of ethanol were added in turn. The combined solution was stirred for $2 \mathrm{~h}$ at $80^{\circ} \mathrm{C}$. During heating, the mixture changed in color from brown to black. Finally, after cooling down to ambient temperature, Pd/DNA was precipitated. Then, by direct decantation, the clear solution was poured out, and Pd/DNA was washed with acetone and dried in vacuo. Pd/DNA (C3) was obtained as a dark powder. (Pd target loading: $2.98 \mathrm{mmol} / \mathrm{g}$ ).

Method 4 (C4): $50 \mathrm{mg}$ of fish sperm DNA was dissolved in $5 \mathrm{~mL}$ of water. Then, $88 \mathrm{mg}$ of $\mathrm{PdCl}_{2}$ and $5 \mathrm{~mL}$ of ethanol were added in turn. The combined solution was stirred for $2 \mathrm{~h}$ at $80^{\circ} \mathrm{C}$. During heating, the mixture changed in color from dark red to black. Finally, after cooling down to ambient temperature, Pd/DNA was precipitated. Then, by direct decantation, the clear solution was poured out, and Pd/DNA was washed with acetone and dried in vacuo. Pd/DNA (C4) was obtained as a dark powder. (Pd target loading: $3.52 \mathrm{mmol} / \mathrm{g}$ ).

\subsection{General Procedure for the Suzuki-Miyaura Reaction}

In a typical reaction, a $50 \mathrm{~mL}$ Schlenk flask was charged with aryl halide $(1 \mathrm{mmol})$, aryl boronic acid $(1.2 \mathrm{mmol})$, base $(1.2 \mathrm{mmol})$, and the Pd/DNA catalyst (containing $0.01 \mathrm{mmol}$ of Pd). Then, $5 \mathrm{~mL}$ of the solvent was added. The resulting mixture was stirred for $2-4 \mathrm{~h}$ at $80{ }^{\circ} \mathrm{C}$. After that time, the Schlenk flask was cooled down, and the organic products were extracted with $3 \times 7 \mathrm{~mL}$ of diethyl ether. The extracts were GC-FID analyzed with dodecane $(0.076 \mathrm{~mL})$ as an internal standard. The products of the reaction were determined by Gas chromatography-mass spectrometry (GC-MS).

\subsection{General Procedure for the Carbonylative Suzuki Coupling Reaction}

In a typical reaction, a $50 \mathrm{~mL}$ Schlenk flask was charged with iodobenzene (1 mmol), phenyl boronic acid $(1.2 \mathrm{mmol})$, base $(1.2 \mathrm{mmol})$, and the Pd/DNA catalyst (containing $0.01 \mathrm{mmol}$ of Pd). Then, $5 \mathrm{~mL}$ of the solvent was added. Under the balloon pressure of $\mathrm{CO}$, the resulting mixture was stirred for $4 \mathrm{~h}$ at $80^{\circ} \mathrm{C}$. After that time, the Schlenk flask was cooled down, and the organic products were extracted with $3 \times 7 \mathrm{~mL}$ of diethyl ether. The extracts were Gas chromatography-flame ionization 
detector (GC-FID) analyzed with mesitylene $(0.076 \mathrm{~mL})$ as an internal standard. The products of the reaction were determined by GC-MS.

\subsection{General Procedure for Pd/DNA Recycling}

After the first run, the Schlenk flask was cooled down and the organic products were extracted with $3 \times 7 \mathrm{~mL}$ of diethyl ether. Then by the aid of centrifugation at $7000 \mathrm{r} / \mathrm{min}$ the catalyst was precipitated. The clear solution was then poured out by direct decantation, and the catalyst was washed with acetone and dried in vacuo. The dried catalyst was used for the next run in order to test its recyclability. Pd/DNA could also be recovered for recycling by simple decantation while filtration was not successful for this catalyst.

\section{Conclusions}

DNA-supported palladium catalysts were prepared using cheap natural DNA at mild conditions in an $\mathrm{EtOH} / \mathrm{H}_{2} \mathrm{O}$ solution. $\mathrm{Pd} / \mathrm{DNA}$ catalysts contained $\mathrm{Pd}(\mathrm{II})$ and up to $45 \%$ of $\mathrm{Pd}(0)$ nanoparticles. EtOH was considered as the main reducing agent in the syntheses of $\mathrm{Pd} / \mathrm{DNA}$, in particular at $80^{\circ} \mathrm{C}$. However some contribution of DNA in reduction of $\mathrm{Pd}(\mathrm{II})$ to $\mathrm{Pd}(0)$ can not be excluded at ambient temperature. This effect will be further studied.

An effect of the palladium precursor and its dosage on the morphology of Pd/DNA was observed. For instance, the catalyst $\mathrm{C} 4$, prepared from $\mathrm{PdCl}_{2}$, contained the biggest nanoparticles and showed the lowest activity in the Suzuki-Miyaura reaction. The $\mathrm{Pd} / \mathrm{DNA}$ catalysts prepared from $\mathrm{Pd}(\mathrm{OAc})_{2}$ exhibited various activities; however, the best result was noted for Pd/DNA containing mainly $\mathrm{Pd}(\mathrm{II})$ and therefore it can be proposed that the most catalytically active $\mathrm{Pd}(0)$ was formed under the catalytic reaction conditions.

The Pd/DNA catalyst showed good stability. It was recycled seven times in the Suzuki-Miyaura reaction with satisfactory results.

$\mathrm{Pd} / \mathrm{DNA}$ showed ability to activate $\mathrm{CO}$ with the tendency to form benzoic acid under carbonylative Suzuki conditions. It is a characteristic feature of Pd/DNA, most probably influenced by the DNA biopolymer. As a consequence, only a limited amount of benzophenone, up to $35 \%$, could be produced in this system.

Our research revealed that DNA interacts with palladium complexes and small molecules [42,43] and $\mathrm{Pd} / \mathrm{DNA}$ is a promising catalyst for coupling reactions.

Supplementary Materials: The following are available online at http:/ / www.mdpi.com/2073-4344/8/11/552/ s1.

Author Contributions: Conceptualization, A.M.T., M.M.; Investigation, M.M., W.T.; Supervision, A.M.T.; Writing-original draft preparation, M.M., W.T.; Writing-review and editing, A.M.T.; Funding acquisition, A.M.T., W.T.

Funding: This work (XPS) was co-financed by a statutory activity subsidy from the Polish Ministry of Science and Higher Education for the Faculty of Chemistry of Wrocław, University of Science and Technology.Financial support of National Science Centre (NCN, Poland) with grant 2014/15/B/ST5/02101 (M.M., A.M.T.) is gratefully acknowledged.

Conflicts of Interest: The authors declare no conflicts of interest.

\section{References}

1. Molnar, A. Palladium-Catalyzed Coupling Reactions, Practical Aspects and Future Development; Wiley-VCH: Weinheim, Germany, 2013.

2. Beletskaya, I.P.; Ananikov, V.P. Transition-Metal-Catalyzed C-S, C-Se, and C-Te Bond Formation via Cross-Coupling and Atom-Economic Addition Reactions. Chem. Rev. 2011, 111, 1596-1636. [CrossRef] [PubMed]

3. Takise, R.; Muto, K.; Yamagushi, J. Cross-coupling of aromatic esters and amides. Chem. Soc. Rev. 2017, 46, 5864-5886. [CrossRef] [PubMed] 
4. Wu, X.-F.; Neumann, H.; Beller, M. Palladium-catalyzed carbonylative coupling reactions between Ar-X and carbon nucleophiles. Chem. Soc. Rev. 2011, 40, 4986-5009. [CrossRef] [PubMed]

5. Shi, S.; Nolan, S.P.; Szostak, M. Well-Defined Palladium(II)-NHC Precatalysts for Cross-Coupling Reactions of Amides and Esters by Selective N-C/O-C Cleavage. Acc. Chem. Res. 2018, 51, 2589-2599. [CrossRef] [PubMed]

6. Tsuji, J. Palladium Reagents and Catalysts. In New Perspectives for the 21st Century; Wiley: Hoboken, NJ, USA, 2004.

7. Liu, C.; Li, G.; Shi, S.; Meng, G.; Lalancette, R.; Szostak, R.; Szostak, M. Acyl and Decarbonylative Suzuki Coupling of N-Acetyl Amides: Electronic Tuning of Twisted, Acyclic Amides in Catalytic Carbon-Nitrogen Bond Cleavage. ACS Catal. 2018, 8, 9131-9139. [CrossRef]

8. Miyaura, N.; Suzuki, A. Palladium-Catalyzed Cross-Coupling Reactions of Organoboron Compounds. Chem. Rev. 1995, 95, 2457. [CrossRef]

9. Suzuki, A. Recent advances in the cross-coupling reactions of organoboron derivatives with organic electrophiles, 1995-1998. J. Organomet. Chem. 1999, 576, 147-168. [CrossRef]

10. Peng, J.B.; Qi, X.; Wu, X.F. Recent Achievements in Carbonylation Reactions: A Personal Account. Synlett 2017, 28, 175-194. [CrossRef]

11. Hussain, I.; Capricho, J.; Yawer, M.A. Synthesis of BiarylsviaLigand-Free Suzuki-Miyaura Cross-Coupling Reactions: A Review of Homogeneous and Heterogeneous Catalytic Developments. Adv. Synth. Catal. 2016, 358, 3320-3349. [CrossRef]

12. Gniewek, A.; Trzeciak, A.M.; Ziółkowski, J.J.; Kępiński, L.; Wrzyszcz, J.; Tylus, W. Pd-PVP colloid as catalyst for Heck and carbonylation reactions: TEM and XPS studies. J. Catal. 2005, 229, 332-343. [CrossRef]

13. Li, Y.; Boone, E.; El-Sayed, M.A. Size Effects of PVP-Pd Nanoparticles on the Catalytic Suzuki Reactions in Aqueous Solution. Langmuir 2002, 18, 4921-4925. [CrossRef]

14. Reetz, M.T.; Westermann, E. Phosphane-Free Palladium-Catalyzed Coupling Reactions: The Decisive Role of Pd Nanoparticles. Angew. Chem. Int. Ed. 2000, 39, 165-168. [CrossRef]

15. Li, Y.; Xiaoyong, M.; Collard, D.M.; El-Sayed, M.A. Suzuki Cross-Coupling Reactions Catalyzed by Palladium Nanoparticles in Aqueous Solution. Org. Lett. 2000, 15, 2385-2388. [CrossRef]

16. Khan, M.; Kuniyil, M.; Shaik, M.R.; Khan, M.; Adil, S.F.; Al-Warthan, A.; Alkhathan, H.Z.; Tremel, W.; Tahir, M.N.; Siddigu, M.R.H. Plant Extract Mediated Eco-Friendly Synthesis of Pd@GrapheneNanocatalyst: An Efficient and Reusable Catalyst for the Suzuki-Miyaura Coupling. Catalysts 2017, 7, 20. [CrossRef]

17. Kozell, V.; Giannoni, T.; Nocchetti, M.; Vivani, R.; Piermatti, O.; Vaccaro, L. Immobilized Palladium Nanoparticles on Zirconium Carboxy-Aminophosphonates Nanosheets as an Efficient Recoverable Heterogeneous Catalyst for Suzuki-Miyaura and Heck Coupling. Catalysts 2017, 7, 186. [CrossRef]

18. Jang, S.; Kim, T.; Park, K.H. Fabrication of Crumpled Ball-Like Nickel DopedPalladium-Iron Oxide Hybrid Nanoparticles with Controlled Morphology as Effective Catalyst for Suzuki-Miyaura Coupling Reaction. Catalysts 2017, 7, 247. [CrossRef]

19. Shabbir, S.; Lee, S.; Lim, M.; Lee, H.; Ko, H.; Lee, Y.; Rhee, H. Pd nanoparticles on reverse phase silica gel as recyclable catalyst for Suzuki-Miyaura cross coupling reaction and hydrogenation in water. J. Organomet. Chem. 2017, 846, 296-304. [CrossRef]

20. Xiong, G.; Chen, X.L.; You, L.X.; Ren, B.Y.; Ding, F.; Dragutan, I.; Dragutan, V.; Sun, Y.G. La-Metal-Organic Framework incorporating $\mathrm{Fe}_{3} \mathrm{O}_{4}$ nanoparticles, post-synthetically modified with Schiff base and Pd. A highly active, magnetically recoverable, recyclable catalyst for C-C cross-couplings at low Pd loadings. J. Catal. 2018, 361, 116-125. [CrossRef]

21. Augustyniak, A.W.; Zawartka, W.; Navarro, J.A.R.; Trzeciak, A.M. Palladium nanoparticles supported on a nickel pyrazolate metal organic framework as a catalyst for Suzuki and carbonylative Suzuki couplings. Dalton Trans. 2016, 45, 13525-13531. [CrossRef] [PubMed]

22. Martinez-Klimov, M.E.; Hernandez-Hipolito, P.; Martinez-Garcia, M.; Klimova, T.E. Pd catalysts supported on hydrogen titanate nanotubes for Suzuki-Miyaura cross-coupling reactions. Catal. Today 2018, 305, 58-64. [CrossRef]

23. Koohgard, M.; Hosseini-Sarvari, M. Enhancement of Suzuki-Miyaura coupling reaction by photocatalytic palladium nanoparticles anchored to $\mathrm{TiO}_{2}$ under visible light irradiation. Catal. Commun. 2018, 111, 10-15. [CrossRef] 
24. Pentsak, E.O.; Cherepanova, V.A.; Ananikov, V.P. Dynamic Behavior of Metal Nanoparticles in Pd/C and Pt/C Catalytic Systems under Microwave and Conventional Heating. ACS Appl. Mater. Interfaces 2017, 9, 36723-36732. [CrossRef] [PubMed]

25. Li, J.; Kong, X.; Jiang, M.; Lei, X. Uniformly dispersed Pd nanoparticles anchored $\mathrm{Co}(\mathrm{OH})_{2} / \mathrm{Cu}(\mathrm{OH})_{2}$ hierarchical nanotube array as high active structured catalyst for Suzuki-Miyaura coupling reactions. J. Mater. Sci. 2018, 53, 16263-16275. [CrossRef]

26. Lu, F.; Astruc, D. Catalytically Active Palladium Nanoparticle-Cored Ferrocenyl-Terminated Dendrimers. Eur. J. Inorg. Chem. 2015, 5595-5600. [CrossRef]

27. Biffis, A.; Centomo, P.; Del Zotto, A.; Zecca, M. Pd Metal Catalysts for Cross-Couplings and Related Reactions in the 21st Century: A Critical Review. Chem. Rev. 2018, 118, 2249-2295. [CrossRef] [PubMed]

28. Tang, L.; Sun, H.; Li, Y.; Zha, Z.; Wang, Z. Highly active and selective synthesis of imines from alcohols and amines or nitroarenes catalyzed by Pd/DNA in water with dehydrogenation. Green Chem. 2012, 14, 3423. [CrossRef]

29. Camacho, A.S.; Martin-Garcia, I.; Contreras-Celedon, C.L.; Chacon-Garcia, F.A. DNA-supported palladium nanoparticles as a reusable catalyst for the copper- and ligand-free Sonogashira reaction. Catal. Sci. Technol. 2017, 7, 2262-2273. [CrossRef]

30. Wang, Y.; Ouyang, G.; Zhang, J.; Wang, Z. A DNA-templated catalyst: The preparation of metal-DNA nanohybrids and their application in organic reactions. Chem. Commun. 2010, 46, 7912-7914. [CrossRef] [PubMed]

31. Itoh, H.; Maeda, H.; Yamada, S.; Hori, Y. DNA-Mediated Palladium Nanoparticles as an Efficient Catalyst for Hydrogenation- and Suzuki-Miyaura Coupling Reactions. ChemCatChem 2012, 4, 1737-1740. [CrossRef]

32. Handbooks of Monochromatic XPS Spectra. Volume 1-The Elements and Native Oxides; XPS International Inc.: Ames, IA, USA; Thermo Fisher Scientific Inc.: Waltham, MA, USA, 2013-2018; Available online: https:/ / xpssimplified.com/elements/palladium.php (accessed on May 2018).

33. Mart, M.; Tylus, W.; Trzeciak, A.M. Pd/DNA as a highly active and recyclable catalyst for aminocarbonylation and hydroxycarbonylation in water: The effect of $\mathrm{Mo}(\mathrm{CO})_{6}$ on the reaction course. Mol. Catal. 2019, 462, 28-36. [CrossRef]

34. Gniewek, A.; Ziółkowski, J.J.; Trzeciak, A.M.; Zawadzki, M.; Grabowska, H.; Wrzyszcz, J. Palladium nanoparticles supported on alumina-based oxides as heterogeneous catalysts of the Suzuki-Miyaura reaction. J. Catal. 2008, 254, 121-130. [CrossRef]

35. Borkowski, T.; Trzeciak, A.M.; Bukowski, W.; Bukowska, A.; Tylus, W.; Kepiński, L. Palladium(0) nanoparticles formed in situ in the Suzuki-Miyaura reaction: The effect of a palladium(II) precursor. Appl. Catal. A Gen. 2010, 378, 83-89. [CrossRef]

36. Narayanan, R.; El-Sayed, M.A. Some Aspects of Colloidal Nanoparticle Stability, Catalytic Activity, and Recycling Potential. Top. Catal. 2008, 47, 15-21. [CrossRef]

37. Whitesides, G.M.; Hackett, M.; Brainard, R.L.; Lavalleye, J.P.P.M.; Sowinski, A.F.; Izumi, A.N.; Moore, S.S.; Brown, D.W.; Sraudt, E.M. Suppression of unwanted heterogeneous platinum(0)catalyzed reactions by poisoning with mercury(0) in systems involving competing homogeneous reactions of soluble organoplatinum compounds: Thermal decomposition of bis(triethylphosphine)-3, 3,4,4-tetramethylplatinacyclopentane. Organometallics 1985, 4, 1819-1830. [CrossRef]

38. Fernandez, F.; Cordero, B.; Durand, J.; Muller, G.; Malbosc, F.; Kihn, Y.; Teuma, E.; Gomez, M. Palladium catalyzed Suzuki $\mathrm{C}-\mathrm{C}$ couplings in an ionic liquid: Nanoparticles responsible for the catalytic activity. Dalton Trans. 2007, 47, 5572-5581. [CrossRef] [PubMed]

39. Phan, N.T.S.; Van Der Sluys, M.C.; Jones, W. On the Nature of the Active Species in Palladium Catalyzed Mizoroki-Heck and Suzuki-Miyaura Couplings-Homogeneous or Heterogeneous Catalysis, A Critical Review. Adv. Synth. Catal. 2006, 348, 609-679. [CrossRef]

40. Wirwis, A.; Gil, W.; Pernak, J.; Trzeciak, A.M. The effect of $\mathrm{Al}_{2} \mathrm{O}_{3}$ and ionic liquids in palladium catalyzed arylation of cyclohexene. Interaction of $\mathrm{Hg}(0)$ with immobilized palladium. J. Mol. Catal. A Chem. 2016, 411, 188-195. [CrossRef]

41. Wójcik, P.; Mart, M.; Ulunkanli, S.; Trzeciak, A.M. Palladium nanoparticles generated in situ used as catalysts in carbonylative cross-coupling in aqueous medium. RSC Adv. 2016, 6, 36491-36499. [CrossRef] 
42. Cusumano, M.; Di Pietro, M.L.; Giannetto, A.; Messina, M.A.; Romano, F. Catalysis and Inhibition of Ligand Substitution in Palladium(II) Square-Planar Complexes: Effects of DNA. J. Am. Chem. Soc. 2001, 12, 1914-1919. [CrossRef]

43. Cusumano, M.; Di Pietro, M.L.; Giannetto, A.; Vainiglia, P.A. The Reaction of (Bipyridyl)palladium(II) Complexes with Thiourea-Influence of DNA and Other Polyanions on the Rate of Reaction. Eur. J. Inorg. Chem. 2005, 2, 278-284. [CrossRef]

(c)

(C) 2018 by the authors. Licensee MDPI, Basel, Switzerland. This article is an open access article distributed under the terms and conditions of the Creative Commons Attribution (CC BY) license (http:/ / creativecommons.org/licenses/by/4.0/). 